\title{
What is the role of Financial Development and Energy Consumption on
}

\section{Economic Growth? New Evidence from North African Countries}

\author{
Doaa M. Salman ${ }^{\text {ai }}$, Eyad M. Atya ${ }^{\mathrm{b}}$ \\ ${ }^{a}$ Associate Professor of Economics, Department of Economics, Modern Sciences and Arts University, MSA, Egypt \\ ${ }^{b}$ Associate Professor of Economics, Department of Economics, Zaggazig University, Egypt
}

\begin{abstract}
This paper aims to test the validity of the causality between financial development and economic growth on energy consumption in three of North African countries. The study employs error coreection model and Granger causaility test to analyza a dataset for three North African countries covering a period from 1980 to 2010. The applied model is based on demand function for energy to assess the existing of causal relationship of energy with financial development, and economic growth, in Algeria, Egypt, and Tunisia. Empirical results provide a positive significant relating financial development and energy consumption in Algeria, and Tunisia. On the other hand, Egypt's results show a negative significant relationship relating energy consumption and financial development. The paper is valuable to policy makers in North African countries in their pursuit for achieving economic growth as it clarifies the urge for the financial development reforms to stimulate investment and growth.
\end{abstract}

Key Words: Financial Development; Economic Growth; Energy consumption.

JEL Classification: $F 43, Q 43, R 32$

(C) 2014 Published by SSBFNET

\section{Introduction}

The investigation for the relationship between energy consumption, economic growth, and financial development in developing countries arises from the need to understand the complex links. Such an understanding is important to regulators and investors in deregulating energy markets and to design a reliable and efficient economic system. The existing of causal relationship between energy consumption, financial development and economic growth is very important for policy makers as it affects directly production, economic growth and development. This study focuses

${ }^{i}$ Corresponding author 
on North Africanb developing countries as they shows a clear divergence in their economic growth. However, the tries to explain the reasons of these difference.

During the mid 1980s, many developing countries attempted to adopt economic reforms targeting high growth performance and to establish a more market-based economy. This move resulted in the subsidized energy prices. Such a subsidize policy has adverse effects; despite the fact that it constitutes an important social safety net for the poor in many parts of the developing countries as well as controls inflation. Therefore, any attempt to reduce or eliminate it that would lead to a decline in households' welfare, inflation increase, a decrease in the competitiveness of certain industries, and an increase in unemployment. The misallocation of resources hinders developing countries from optimizing the use of its reserves, leads to exceptionally high consumption growth rates for energy, lowers incentives for productivity improvements and investments in more energy-efficient technology, distorts pricing, and results in a lack of incentives for investment in alternative energies.

This study tries to investigate for the relation between financial development and economic growth relationship with energy consumption. Thus it selects four countries two are classified as oil-rich economies (Algeria and Egypt) and Tunisia as oil scare resources. The countries under study record a rapid growth in consumption of the various primary fuels and electricity regardless of what they own. In Algeria, oil and natural gas are the main exported products during years 1980 to 2010 and total primary energy production and consumption doubled during 1990 to 2010 (EIA, 2012). In 2010, Algeria was the fourth largest crude oil producer in Africa after Nigeria, Angola, and Libya. In 2010, Algeria was the eighth largest natural gas producer in the world and Egypt was the second largest natural gas producer on the continent.c In the 1980's and 1990's, Egypt played an important role in oil exporting. This continued until the early 2000 's. Up till the year 2006, the production of petroleum was more than the consumption, so we exported the difference. From the year 2007 the production started declining and the consumption started rising to use the entire amount produced. As from 2008 till 2012 the consumption surpasses the production causing us to import oil from Iraq and Libya, see table 1 - in the appendix.

In 2010, Egypt produced roughly 2.2 trillion cubic feet (Tcf) and consumed just over $1.6 \mathrm{Tcf}$ of dry natural gas. Gas production is expected to continue growing to satisfy the domestic rising demand and export commitments through the Gas Pipeline. Thus, Egypt is expected to continue to be an important natural gas supplier to Europe and the Mediterranean region; however, exports are competing with domestic rising demand, particularly in Egypt's power generation sector. Moreover, Egypt is the largest non-OPEC oil producer in Africa. In 1990, oil production recorded the peak for more than $900,000 \mathrm{bbl} / \mathrm{d}$. Output began to increasingly decline as oil fields matured, see table 1 - in the appendix..

Accordingly, as consumption increased Egypt's imports of both crude oil and refined petroleum products increased to make up for the decreased oil output. Although Egypt has the largest oil refining sector in Africa, a small volume of

\footnotetext{
${ }^{\mathrm{b}}$ North African countries includes: Algeria, Egypt, Libya, Morocco, Sudan Tunisia, and Western Sahara.

${ }^{\mathrm{c}}$ Country energy briefs, Energy information agency. www.wia.doe.gov
} 
refined petroleum product imports are used to meet domestic demand.d Over the last decade domestic oil consumption has grown by over $50 \%$ during 2000 through 2010. In addition, total electricity consumption and generation have both grown by more than 100\% from 1990 to 2010, (EIA, 2012). Most of Egypt's power demand growth comes from the growing industrial sector. In oil - scarce resource countries, such as Jordan they rely on imported oil and natural gas from neighboring countries.

In Tunisia, the total primary energy production increased by $23 \%$ during the period 1990 to 2010 , faced by an increase in consumption of $40 \%$ during the same period. The highest level of production can be observed in the gas sector by which production increased from 12 BCF in 1990 to record 72 BCF, (EIA, 2012). Tunisia receives natural gas from a pipeline between Algeria and Italy that runs across the Tunisian territory. In cooperation, in 2007 this led to an even energy balance for the first time in recent years. In Tunisia, the industrial sector is the largest energy consumer. By 2010, the total power generating capacity recorded 15.4 billion kilowatt hours to exceed the domestic consumption. The need for energy is increasing with the increase of population in the four countries. Such an increase in consumption coupled with aging and inefficient infrastructure pose as a challenge with a demanding need to increase capital investment and update infrastructure. On the environmental side, total $\mathrm{CO} 2$ emission (measure in million metric tons - MMT) is increasing in the four countries. In Algeria it increased by 33\%, Egypt increased by $113 \%$, Jordan increased by $87 \%$, and Tunisia by $43 \%$ during the period 1990 to 2010, (EIA, 2012).

Finally the level of economic development in these countries confirms the wide divergence on their level of development, real GDP per capita from \$ 4567 in Algeria to \$2698 in Egypt, while in Jordan and Tunisia it doesn't exceed $\$ 4300$ in 2010, (EIA, 2012).

In the 1990s, many developing countries started financial reform targeting sound financial systems, thus trying to improve the capacity of financial institutions in order to mobilize domestic saving, improving the effectiveness of monetary policy and enhancing a soundness financial system. Despite adopting the same objective among developing countries, the speed and the implemented policy is different across countries. In Algeria, Egypt, Libya, Sudan, Syria, and Tunisia; public banks continue to control the financial sector whereby domestic credit is not utilized in terms of the expected productivity of potential investment, thus accumulating a large ratio of nonperforming loans, (Elhag et al., 2000). In Algeria, the financial system plays a minor role as it is in its infancy stage, on the contrary Egypt stock market is from the oldest financial system. The Algerian Stock Exchange was officially opened in 1999, this late opening lead to a slow the progress of financial lending services. In 2008, stock market indicators increased to record 27 billion dollars in Amman, 65 billion dollars in Egypt, and 1.4 billion dollars in Tunisia. In 2012, Amman, Egypt and Tunisia stock markets dropped dramatically to record a low turnover ratio, as well the ratio of values shares traded in percentage of market capitalization (WDI, 2012). The low turnover ratio of bourses reflects a serious illiquidity problem especially in Arab spring stock markets. Financial development provides a main channel of funds to boost investment projects, achieve higher levels of productive efficiency, and to expand in production requiring an increase

\footnotetext{
${ }^{\mathrm{d}}$ Country energy briefs, Energy information agency. www.wia.doe.gov
} 
in energy consumption. Energy plays a role in economic growth via production. This implies that financial development and economic growth may have effects on energy consumption.

Researchers investigate for the role of financial development in economic growth. However, the interpretation changes among researchers. Some added it as proxy for efficiency gain; others interpreted it as an institutional development which enables economic units to consume more energy. In this paper, tries to report the role of financial development and economic growth on energy consumption in North African countries. The paper is desgined to start by focusing on the literature review through giving a brief on the links between energy and financial sector contribution. Secondaly, an empirical analysis will follow. Last but not least, is the conclusion of the results will be displayed.

\section{Literature Review}

The review of existing literature in the field of Finance-Growth shows that studies in this area mainly focus on either testing whether financial development plays a positive role in stimulating economic growth or examining the direction of causality between these two variables. There are many cross-country empirical studies that support the positive association between financial development and economic growth. The first study on finance and growth is conducted by Goldsmith (1969) using data on 35 countries over the period from 1860 to 1963, using the value of financial intermediary assets as a share of economic output, the author assumed that the size of the financial intermediary sector is positively correlated with the quality of financial functions provided by the financial sector. Goldsmith graphically documented a positive correlation between financial development and the level of economic activity. However, the author did not come up with a definite conclusion about causal relationship between financial development and economic growth.

In this study it tries to assess whether there is a relation or not between energy and economic growth this must need a proof. There are countries that are blessed with enregy reources but they have a weak economic growth. Other countries have no energy resources but they are excelling regarding economic growth and are considered developed countries. On the other hand, some countries have different energy resources but are not doing well economically and are still considered developing. The financial sector of a country can play a very big role in the development of the economy, even though it is not a direct factor. The flow of money to the public provide assistance in term of investment, liquidity and the provision of insurances all comes from the financial sector and directing toward development. In Rostow's growth theory to acheive development countrles passes through five stages of development. By looking look into these stages for example it starts by factor driven countries and end by wealth stage. İn the factor of production stage, the country is moving from a traditional society which acts a self-sufficient and simple to a market economy. Where human capital plays a role along with the introduction of the entrepreneurship, which later introduces the possibility of matching demand and supply via intermediary entities. İn other words countries depending on factor of production and need to bloom than there they have to be innovation and systematic rule, it can't remain random. This is why banks and other financial institutions play a vast role in achieving growth, because they match the demand for money with its supply, which is a factor that can increase investment and capital accumulation and achieve profits. 
Recent studies discuss the outcome of financial development on economic growth, Levine, R. (1996), Bairer, et al. (2004) and Abu Badier and Abu Qarn (2008) showed that development of technology, cutting information cost, and the gains of investment enhance financial system efficiency and effectiveness. The importance of financial system development relies on its effect on economic growth. Goldsmith (1969), Beakert and Harvey (2000), Beakert et al. (2005), and Fung (2009) argues that liberalization of financial markets robust growth. Moreover, the endogenous growth theory shows that there is a significance impact of financial development on economic growth in the long run through the financial services and technological innovastion. Greenwood and Boyan (1990), Bencivenga and Smith (1991) lists these services in mobilizing savings, acquiring information about investments, allocating resources, monitoring managers, exerting corporate control, and facilitating risk amelioration. On the other hand, Robinson (1952), Lucas (1988), and Stern (1989) argue that financial development is a result of economic growth. This would indicate, contrary to endogenous growth theorists, that causality, if it exists, runs from economic growth to financial development. In this arena King and Levine (1993), supported the positive and significant relationship between financial development and economic growth.

Scholar's such as Stiglitz (2000), Rogoff (2004), and Arestis and Stein (2005) advise that steps taken toward financial development and financial liberalization may be harmful to the economy in the absence of scanning the prevailing economic situation. There are many indicators that had been usedfor financial development such as: currency to gross domestic product, stock market capitalization which involve the promotion of trading activities. Levine (2003) shows that domestic credit to private sector is a very good proxy of financial development. As it provide the actual amount of funds collected from savers and distributed by banks to investors for investing in high return projects. This proxy represnt a better indicator of financial deepening.

Morover, a number of studies examine and measure different countries' financial development relationship with economic growth. Ghali (1999) shows that financial deepening promoted economic growth in Tunisia over the period 1963-93, using bank deposit liabilities/GDP ratio and private credit/GDP ratio as alternative measures of financial development. Furthermore, Al-Awad and Harb (2005) use both panel and individual country cointegration for ten MENA countries for within the period of 1969-2000. They based their analysis on a single financial measure, namely, the ratio of private credit to monetary base. Their co-integration results strongly support the existence of a long-run relationship between the two variables, but fail to clearly establish the direction of causality. Another study by Boulila and Trabelsi (2004) addresses the finance-growth nexus in 16 MENA countries. This study supports the view that causality runs from real economy to the financial sector. In a recent paper by Abu- Bader and Abu-Qarn (2008) strong evidence was found for bi-directional causality between the two variables.

Furthermore, the relationship between energy consumption and economic growth has been synthesized into four testable hypotheses through empirical studies, Apergis and Payne (2009). The first hypothesis is that energy consumption is a precondition for economic growth given that energy is a direct input in the production process and an indirect input that complements labor and capital inputs. In 2010, Oztruk and Acaravci provide a detailed literature 
review on the relationship between energy- growth. Morover, Sadorsky (2010) used different indicatorse of financial development in twenty two emerging economies between the period1990-2006. His research results provide a positive significant impact of financial development on energy demand. Shahbaz et al. (2012) suggested a significant and positive effect of financial development on energy consumption in Tunisia. In Malaysia, Islam et al. (2011) revealed that financial development and economic growth have positive impact on energy consumption. In comparison to Pakistan, a unidirectional causality was found running from financial development to energy consumption in Malaysia.

The second hypothesis emphasizes that the relationship begin from economic growth leading to more energy consumption. But in this hypothesis several authors drew different conclusions. Selden and Song (1994) and Galeotti, Manera and Lanza (2009) provide empirical evidence on the validity of environmental Kuznets curve hypothesis. However, Holtz-Eakin and Selden (1995) found a monotonic rising curve and Friedl and Getzner (2003) found an Nshaped curve. Another group of researchers shows that ther is no relationship between economic growth and environmental pollutants, (Agras and Chapman, 1999; Richmond and Kaufman,2006). The third hypothesis assumes a bidirectional relationship between energy consumption and economic growth. Ozturk and Acaravci (2010) revealed the bidirectional causal relation between energy consumption and economic growth in Hungary. In the United Kingdom, Altunbas and Kapusuzoglu (2011) found no long-run causality between energy consumption and economic growth, and short run unidirectional causality runs from economic growth to energy consumption.

Finally, the fourth hypothesis assumes that there is no causality between energy consumption and economic growth (known as the neutral hypothesis). Asafu-Adaye (2000) and Jumbe (2004) believe that policies targeting conserving energy do not slow down economic growth. Lutkepohl (1982) argued that omissions of important variables provide biased and inappropriate results on the relationship. Recently, Bartleet and Gounder (2010) also recommended incorporating other pertinent variables that also play an important role to elucidate the energy growth nexus.

\section{Data and Model}

The applied model is based on demand function for energy to examine causal relationship between energy consumption, financial development, and economic growth, foreign direct investment in Algeria, Egypt, and Tunisia. The sample used is annual data covering the period 1980-2010 taken from the World Development Indicators (WDI$\mathrm{CD}, 2012$ ). In this paper energy consumption is used to capture the demand for oil per capita in each country, real GDP per capita to represent the economic growth, DCPBS to the role financial development, FDI capture net inflows of foreign direct investment and it is used as the proxy of capital market openness. Following to the above discussion, we consider the empirical equation following the demand function framework as given below:

$$
\text { Energy }=\beta_{0}+\beta_{1} G D P_{t}+\beta_{2} D C P B S_{t}+\beta_{3} F D I+\varepsilon
$$

Energy: energy consumption is measured by $\mathrm{kg}$ of oil equivalent per capita

\footnotetext{
${ }^{\mathrm{e}}$ FDI, bank deposits as share of GDP, stock market capitalization as share of GDP, stock market turnover ratio and total stock market value traded over GDP
} 
GDP: is the real GDP per capita (constant 2000 US\$)

DCPBS: Domestic credit provided by banking sector (\% of GDP) is used as proxy for financial development.

FDI: is foreign direct investment is measured by net inflows (\% of GDP). All the data are obtained from world development indicators data base.

$\varepsilon_{t}:$ is error term. All variables are transformed into natural logarithms.

\section{Empirical results}

The empirical part tarts by testing variable using Unit Root tests. To test for all variable stationarity in the time series the Augmented Dickey-Fuller (ADF) is implemented. As observed, the results reveal that variables for rich oil resources, in Algeria, energy and GDP are stationary in the first difference, but GDPBS is stationary in its level. In Egypt, Foreign direct investment, DCPBS are stationary in their levels; energy use and GDP are stationary in the first level. While for oil- scarce resources, Tunisia, DCPBS is stationary in its levels; energy use, FDI, and GDP are stationary in the first difference, see table 2.

Table 2: Augmented Dickey-Fuller unit root tests

\begin{tabular}{|c|c|c|c|c|c|c|c|c|c|c|c|c|c|c|}
\hline $\begin{array}{c}\text { Variable } \\
\quad \mathrm{s}\end{array}$ & 㫄 & Constant & $\underset{\Xi}{60}$ & $\begin{array}{l}\text { Constant } \\
\& \text { trend }\end{array}$ & $\begin{array}{c}\text { Variable } \\
\text { s }\end{array}$ & 点 & Constant & $\underset{\Xi 0}{\mathscr{E}}$ & $\begin{array}{l}\text { Constant } \\
\& \text { trend }\end{array}$ & $\begin{array}{c}\text { Variable } \\
\mathbf{s}\end{array}$ & 点 & Constant & $\underset{\Xi 0}{\mathscr{E}}$ & $\begin{array}{c}\text { Constant } \\
\& \text { trend }\end{array}$ \\
\hline Algeria & & & & & Egypt & & & & & Tunisia & & & & \\
\hline Denergy & 0 & $-4.645 * * *$ & 0 & $-4.588 * * *$ & Denergy & 0 & -0.3666 & 1 & $-3.710 * *$ & Denergy & 0 & $-8.414 * * *$ & 0 & $-8.258 * * *$ \\
\hline GDP & 1 & -0.7025 & 1 & 1.098 & GDP & 3 & 0.6735 & 1 & -3.0922 & DGDP & 0 & $-4.963 * * *$ & 1 & -2.84065 \\
\hline DGDP & & $-2.9227 *$ & 0 & -3.129 & DGDP & 0 & $-3.904 * *$ & 2 & $-3.5631^{*}$ & DCPBS & 3 & $-3.866 * * *$ & 3 & $-3.5687^{*}$ \\
\hline DCPBS & 0 & $3.016 * * *$ & 1 & -0.392 & DCPBS & 5 & $-4.17 * * *$ & 5 & $-4.48 * * *$ & FDI & 1 & 0.184 & 1 & -1.4409 \\
\hline FDI & 1 & 0.1841 & 1 & -1.44 & FDI & 1 & $-3.090 * *$ & 1 & $-3.4099 *$ & DFDI & 0 & $-2.8222 *$ & 1 & -1.4409 \\
\hline
\end{tabular}

$(*),\left({ }^{* *}\right)$ and $\left({ }^{* * *}\right)$ indicate $10 \%, 5 \%$ and $1 \%$ level of significant, respectively. Akaike Information Criteria (AIC) is used to select the lag length; DX represents the first difference of variable $\mathrm{x}$

Next step is employing a panel co-integration analysis: To determine whether the regressions are spurious, the results of the Johansen co-integration tests must be examined, to test for the presence of long-run relationship. The results of Johansen's based on Fisher's tests (trace tests statistics) supported the presence of a co-integrated relationship between the variables at $5 \%$ significant level, see table 3 .

Table 3: Johansen co-integration tests results

\begin{tabular}{|c|c|c|c|c|c|c|c|c|c|c|c|}
\hline 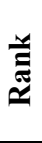 & $\begin{array}{l}\text { Eigen } \\
\text { value }\end{array}$ & $\begin{array}{c}\text { Trace } \\
\text { statistic }\end{array}$ & $\begin{array}{c}\mathbf{5 \%} \\
\text { Critical } \\
\text { value }\end{array}$ & 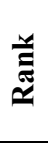 & $\begin{array}{l}\text { Eigen } \\
\text { value }\end{array}$ & $\begin{array}{c}\text { Trace } \\
\text { statistic }\end{array}$ & $\begin{array}{c}5 \% \\
\text { Critical } \\
\text { value }\end{array}$ & 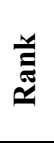 & $\begin{array}{l}\text { Eigen } \\
\text { value }\end{array}$ & $\begin{array}{c}\text { Trace } \\
\text { statistic }\end{array}$ & $\begin{array}{c}5 \% \\
\text { Critical } \\
\text { value }\end{array}$ \\
\hline \multicolumn{4}{|c|}{ Algeria } & \multicolumn{4}{|c|}{ Egypt } & \multicolumn{4}{|c|}{ Tunisia } \\
\hline 0 & . & 50.3001 & 47.21 & 0 & & 61.7313 & 47.21 & 0 & . & 47.4039 & 47.21 \\
\hline 1 & 0.6588 & $26.6432 *$ & 29.68 & 1 & 0.63989 & 33.1337 & 29.68 & 1 & 0.53535 & $25.9428 *$ & 29.68 \\
\hline 2 & 0.4733 & 12.5378 & 15.41 & 2 & 0.55032 & $10.755^{*}$ & 15.41 & 2 & 0.42648 & 10.3759 & 15.41 \\
\hline 3 & 0.2937 & 4.8876 & 3.76 & 3 & 0.31405 & 0.2007 & 3.76 & 3 & 0.30798 & 0.0679 & 3.76 \\
\hline 4 & 0.1992 & & & 4 & 0.00714 & & & 4 & 0.00242 & & \\
\hline
\end{tabular}


Table 3 presents the results of trace tests and maximum Eigen value tests. For Algeria, the null hypothesis $(\mathrm{H} 0)=1$ is not rejected, so there is one long-run relationship among the variables, where trace statistics $(26.6432)<$ critical statistics (29.68) at $5 \%$ level. In Egypt, the null hypothesis $(\mathrm{H} 0)=2$ is not rejected, so there are two long-run relationship among the variables, where trace statistics $(10.7553)<$ critical statistics $(15.41)$ at $5 \%$ level. Finally, in Tunisia, the null hypothesis $(\mathrm{H} 0)=1$ is not rejected, so there is one long-run relationship among the variables, where trace statistics $(25.9428)<$ critical statistics $(29.68)$ at $5 \%$ level. Finally the countries, present the rank is more than zero, which means that there is a long-run relationship among the variables in the four countries.

To determine the existing of short and long term relation an error correction models (ECMs) is applied. ECMs results are useful for estimating both short term and long term effects of one time series on another. Theoretically-driven approach to estimating time series models, ECMs are useful models to determine integrated data, but can also be used with stationary data.

$\Delta$ Energy $_{t}=\propto+\beta_{1} \Delta G D P_{t-1}+\beta_{2} \Delta D C P B S_{t-1}+\beta_{2} \Delta D F D I_{t-1}+\beta_{3} \mathrm{EC}_{\mathrm{t}-1}+\varepsilon$

Where EC is the error correction component of the model and measures the speed at which prior deviations from equilibrium are corrected. To investigate for co-integration between the variables then the error correction model must be constructed first to estimate the relationships. Table 4 shows there is a direct positive and significant relationship between energy consumption and economic growth in Egypt, and Tunisia, but there is positive relationship but it is not significant for Algeria.

Table 4: Error Correction Model results

\begin{tabular}{cccc}
\hline & Algeria & Egypt & Tunisia \\
\hline \multirow{2}{*}{ GDP } & 0.3125758 & $1.034193^{* * *}$ & $0.5686396^{* * *}$ \\
& -0.2313361 & -0.05941 & -0.1058701 \\
\multirow{2}{*}{ DCPBS } & $0.1939577^{* * *}$ & $-0.2174408^{* *}$ & $0.8009607^{* * *}$ \\
& -0.048236 & -0.0961169 & -0.2197207 \\
\multirow{2}{*}{ FDI } & $0.0318881^{* * *}$ & $0.0977771^{* * *}$ & -0.1246293 \\
& -0.0077989 & -0.0168378 & -0.2413862 \\
\hline
\end{tabular}

Results for economic growth supported literature first hypothesis, that economic growth lead to an increase in energy consumption. Though economic growth in Egypt, and Tunisia relies on energy consumption except in Algeria despite it is one of oil rich countries. This result supported Birol, F. et al. (1995) where the impact of subsidy phase's out in Algeria whether it is given to the consumer (at the pump) or to the producer (refineries) which adversely affects the economy. Subsidized energy markets ultimately work against the goal of promoting economic development.

Financial development results provide a positive significant relationship between financial development and energy consumption in Algeria, and Tunisia. For Egypt, there is a negative significant relationship between energy consumption and financial development. The financial reforms and recent development in the petroleum sectors did not solve government budget deficit due to their failure of managing the subsidies programs and the persist increase in 
the energy consumption. The rapidly rising demand for energy reflects negatively on the pricing policy. Furthermore, foreign direct investment shows a positive and significant relationship between foreign direct investment and energy consumption in Egypt, Algeria. While in Tunisia, there is a negative insignificant relationship. The negative relation means that more efficient technology of foreign firms can indeed contribute to an energy reducing technique effect via technology transfer.

Empirical results provide a negative relationship between financial development and energy consumption. The Egyptian government faces an increasing demand for energy sources from population and industries under its subsidies policy. Such policies increase the government debt and reflect negatively on the financial development. Empirical results provide a positive relationship between energy consumption and economic growth with a significance of $1 \%$. On the other hand, foreign direct investment has a positive, yet insignificant the issue that need redesigning and a better incentives programs to attract more investments. In Tunisia, results supported the positive relationship between economic growth, financial development and energy consumption with a significance of 5\%. Tunisia registered a deficit in its energy balance on 1990 and 2010. That is why it is very crucial to find others sources of energy like the renewable energies. The results indicated that there is a negative relationship between foreign direct investment and energy consumption, but insignificant.

The study concluded that these countries are in need to adopt more energy and financial reform programs and adjust energy pricing. Such reforms may indeed be a medium- to long-term endeavor. Finally, since energy consumption is essential for these countries and participates in their economic growth, then increasing energy productivity via energy saving projects is urged. Furthermore, government should encourage investments on research and development to articulate new energy savings technology to sustain economic growth and sustainable development.

\section{Conclusion}

This study investigated the effects of economic growth and financial development on energy consumption in the three countries, namely, Algeria, Egypt, and Tunisia. The study used time series data over the period of 1980-2010. Empirical evidence analyzed each country's situation separately. In Algeria, economic growth relationship with energy showed a positive but insignificant relation, reflecting the government's fragile energy policy and the urgent need to adopt an effective energy policy to robust economic growth through energy pricing reforms. While financial development showed a positive significant relation despite the recent establishment of the Algerian stock market. Unlike any country under study, Algeria provides a bidirectional relation between energy consumption and financial development, thus supporting results by Sadorsky. Moreover, foreign direct investments provide a positive significant relationship provides that Algeria is a rewarding environment especially after oil pricing reforms. In Egypt, economic growth relies on the subsidized energy resources as a tool to attract investment, increase production and lower unemployment. 


\section{References}

Abu-Bader, S., \& Abu-Qarn. (2008). Financial development and economic growth: the Egyptian experience. Journal of Policy Modeling .30: 887-898.

Agras, J., Chapman, D. (1999). A Dynamic Approach to the Environmental Kuznets Curve Hypothesis. Ecological Economics, 2, 267-277.

Al-Awad, Mouawiya, and Nasri H. (2005). Financial Development and Economic Growth in the Middle East. Applied Financial Economics, 15, 1041-51.

Altunbas, Y., Kapusuzoglu, A., (2011). The causality between energy consumption and economic growth in United Kingdom. Economic Research, 9, 330-335.

Apergis, N., Payne, J.E. (2009). Energy consumption and economic growth in Central America: evidence from a panel co-integration and error correction model. Energy Economics, 31, 211-216.

Arestis, P., Stein, H. (2005). An institutional perspective to finance and development as an alternative to financial liberalization. International Review of Applied Economics, 18, 381-398.

Asafu-Adaye J. (2000). The relationship between energy consumption, energy prices and economic growth: time series evidence from Asian developing countries. Energy Economics, 22, 615-625.

Bairer, S.L., Dwyer Jr, G.P. (2004). Tamura, R. Does opening a stock exchange increase economic growth? Journal of International Money and Finance, 23, 311-331.

Bartleet, M., and Gounder, R. (2010). Energy consumption and economic growth in New Zealand: results of trivariate and multivariate models. Energy Policy, 38, 3505-3517

Beakert, G., Harvey, C.R. (2000). Foreign speculators and emerging equity markets. Journal of Finance, 52: 565-614.

Beakert, G., Harvey, C.R., and Lundblad, C. (2005). Does financial liberalization spur growth? Journal of Financial Economics, 77, 53-55

Bencivenga, Valerie R. and Bruce D. Smith, (1991). Financial Intermediation and Endogenous Growth. Review of Economic Studies, 58, 195-209.

Birol, F., Aleaha Av., Ferrouk R. (1995). The Economic Impact of Subsidy Phase Out in Oil Exporting Developing Countries: A Case Study of Algeria, Iran, and Nigeria, Energy Policy. 23, 209-215.

Boulila, Ghazi, Mohamed Trabelsi, (2004). The Causality Issue in the Finance and Growth Nexus: Empirical Evidence from Middle East and North African Countries. Review of Middle East Economics and Finance, 2, 123-38.

Dickey D.A, Fuller W.A. (1979). Distribution of the Estimators for Autoregressive Time Series with a Unit Root. Journal of the American Statistical Association, 74, 427-431.

Elhag, M., A. Fedelino and K. Nashashibi. (2000). Financial crisis liberalization in Arab countries: An overview, seminar on Monetary and fiscal policies, Damascus.Available at: http://www.irtipms.org/OpenSave.asp?pub=215.pdf Friedl, B., Getzner, M. (2003). Determinants of CO2 Emissions in a Small Open Economy. Ecological Economics, 1, 133-148. 
Fung, H.K. (2009). Financial development and economic growth: convergence or divergence? Journal of International Money and Finance, 28, 56-78.

Galeotti, M., Manera, M.,and Lanza, A. (2009). On the Robustness of Robustness Checks of the Environmental Kuznets Curve Hypothesis. Environmental and Resource Economics, 4, 551- 574.

Ghali, Khalifa H. (1999). Financial Development and Economic Growth: The Tunisian Experience. Review of Development Economics, 3, 310-22.

Goldsmith, R. W. (1969). Financial Structure and Development, New Haven, CT: Yale University Press.

Greenwood, J. and Boyan J. (1990). Financial Development, Growth, and the Distribution of Income. Journal of Political Economy, 98, 1076-1077.

Holtz-Eakin, D., and Selden, T.M. (1995). Stroking the Fires: CO2 Emissions and Economic Growth. Journal Public Economics, 1, 85-101.

Islam, F., Shahbaz, M., Alam, M. (2011). Financial Development and Energy Consumption Nexus in Malaysia: A Multivariate Time Series Analysis. MPRA Study 28403, University Library of Munich, Germany.

Jumbe CBL. (2004). Co-integration and causality between electricity consumption and GDP: empirical evidence from Malawi. Energy Econonomics, 26, 61-68.

Khan, M. S., Senhadji, A. S. (2000). Financial development and economic growth: an overview. IMF Working Paper, $\mathrm{WP} / 00 / 209$

King, R.G., and Levine, R. (1993). Finance and growth: Schumpeter might be right. Quarterly Journal of Economics, $08,717-738$.

Levine, R. (1996). Financial Development and Economic Growth: Views and Agenda. Policy Research Working Study Series 1678. The World Bank

Levine, R., 2003. More on finance and growth: more finance, more growth? Review, Federal Reserve Bank of St. Louis, 31-46.

Lucas, R.E. (1988). On the mechanism of economic development. Journal of Monetary Economics, 22, 3-42.

Lütkepohl, H. (1982). Non-causality due to omitted variables. Journal of Econometrics, 19, 267-378.

Richmond, A.K., Kaufmann, R.K. (2006). Is there a Turning Point in the Relationship between Income and Energy Use and/or Carbon Emissions? Ecological Economics, 2, 176-189.

Robinson, J. (1952). The generalization of the general theory. In: The Rate of Interest and Other Essays. MacMillan, London.

Rogoff, K. (2004). Extending the limits of global financial integration. Journal of Policy Modeling, 26, 519-523.

Ozturk, I., Acaravci, A. (2010). The causal relationship between energy consumption and GDP in Albania, Bulgaria, Hungary and Romania: evidence from ARDL bound testing approach. Applied Energy, 87, 1938-1943.

Sadorsky, P. (2010). The impact of financial development on energy consumption in emerging economies. Energy Policy, 38, 2528-2535.

Selden, T.M., Song, D. (1994). Environmental Quality and Development: Is there a Kuznets Curve for Air Pollution Emissions? Journal of Environmental Economics and Management, 2, 147- 162. 
Shahbaz, M., Islam, F., Islam, M.M. (2012). Does financial development increase energy consumption? The role of industrialization and urbanization in Tunisia. Energy policy, 40, 473- 479.

Stern, N. (1989). The economic development: a survey. Economic Journal, 100, 597-685.

Stiglitz, J. (2000). Capital market liberalization, economic growth, and instability. World Development, 28, 10751086. 
APPENDIX

Table 1: Overview of energy production and consumption

\begin{tabular}{|c|c|c|c|c|c|c|c|c|c|}
\hline \multirow{2}{*}{ Energy source } & \multicolumn{3}{|c|}{ Algeria } & \multicolumn{3}{|c|}{ Egypt } & \multicolumn{3}{|c|}{ Tunisia } \\
\hline & 1980 & 1990 & 2010 & 1980 & 1990 & 2010 & 1980 & 1990 & 2010 \\
\hline \multicolumn{10}{|l|}{ Petroleum } \\
\hline Consumption & 121.3 & 194 & 351.53 & 260 & 465 & 698 & 52 & 63.2 & 88.4 \\
\hline Production & 1143 & 1314.6 & 1879.15 & 613 & 901.4 & 714.8 & 110 & 97.7 & 83.7 \\
\hline \multicolumn{10}{|l|}{ Natural Gas } \\
\hline Consumption & 460 & 681 & 1017.8 & 30 & 286 & 1,631 & 12.7 & 54 & 115.8 \\
\hline Production & 411 & 1787 & 2988 & 30 & 286 & 2165.9 & 12.7 & 12 & 72 \\
\hline \multicolumn{10}{|l|}{ Electricity } \\
\hline Net Generation & 6.68 & 15.145 & 42.83 & 18.26 & 41.41 & 139 & 2.62 & 5.21 & 15.14 \\
\hline Net Consumption & 5.91 & 12.73 & 33.67 & 15.86 & 37.2 & 122.37 & 2.26 & 4.59 & 13.29 \\
\hline \multicolumn{10}{|l|}{ Coal } \\
\hline Consumption & 672.4 & 1205.9 & 434.31 & 864.2 & 1606 & 1,001 & 99.2 & 121.3 & 0 \\
\hline Production $^{\text {a }}$ & 7.72 & 11.023 & & 0 & 0 & 26.4 & 0 & 0 & 0 \\
\hline \multicolumn{10}{|l|}{ Total Energy } \\
\hline Primary production & 2.8 & 4.75 & 7.06 & 1.45 & 2.36 & 4 & 0.24 & 0.22 & 0.27 \\
\hline Primary consumption & 0.8 & 1.22 & 1.84 & 0.71 & 1.44 & 3.39 & 0.13 & 0.22 & 0.307 \\
\hline \multicolumn{10}{|l|}{ Indicators } \\
\hline Total $\mathrm{CO}_{2}$ Emission & 66.98 & 83.12 & 110.91 & 40.92 & 92.63 & 197 & 8.48 & 13.05 & 18.72 \\
\hline Per Capita Carbon Dioxide Emissions & 3.562 & 3.3129 & 3.2065 & 0.959 & 1.687 & 2.4424 & 1.32 & 1.58 & 1.768 \\
\hline Population & 18.806 & 25.089 & 34.5861 & 42.634 & 54.9 & 80.471 & 6.44 & 8.211 & 10.589 \\
\hline GDP per capita (current US\$) & 2251 & 2452 & 4567 & 509 & 758 & 2698 & 1369 & 1507 & 4194 \\
\hline
\end{tabular}

Notes: Petroleum production and consumption measured in thousands of barrels per day. Natural gas production and consumption measured in billion cubic feet. Coal production and consumption measured in million short tons. Electricity production and consumption measured in billion kilowatt hours. Data on petroleum, natural gas, coal, and electricity consumption were obtained from the Energy Information Agency-International Energy Data and Analysis (www.eia.doe.gov). a - Coal data represented in 2009 year 